の頸部伸展位は頭部受台の調節ハンドルで頭部を低くす るととにより可能である. 頭部固定はアクリル樹脂によ り両側よりサンドイッチ式に固定する.動脈像, 毛細血管 像, 静脈像にいたる過程の連続撮影はカセッテ挿入箱に 3 枚のカセッテをカセッテホルダーに入れて插入する. 動脈像の撮影が終わると同時に1枚を引き抜くとスプリ ングにより，次のカセッテが位置する，カセッテホルダ 一の裏面は鉛 1 ミりを張り付け，X線をしゃ断している. （簧問）

背臥位，腹臥位の場合の撮影はどうなるのか。（奈良 森川)

(答)

台が自由に調節できるようになっている（川上）

\section{3）小児兼用胸部間接摆影機について（第1 報）}

兵庫県西宮市役所

○林 篤雄 大阪大学病院放科

遠藤 俊夫・山下 一也・森 嘉 信

\section{I 諸，言}

現在, 小学校 3 年までの児童および，幼児については， フードを取り換えて撮影を行なっているが，小児用フー ド取り換え操作には多くの時間と労力を要し，乙れがた めに結核予防法に基ずく検晾において，実際上，ツベル クリン自然陽転者の撮影は, その場で実施するととがで きず，行なったとしても大人用フードのままで行なうた め胸部がフィルムの一部に小さく写り診断価值の乏しい 写真に甘んじなければならない，小児用フード取り換え 操作によって生ずるミスすまた，多く，最近のオートメ 化された設備においては，小さなるスも大きな失敗とな り，なお一周の煩さとなりますが，乙のような煩さとる スをなくし，結核予防法に基ずく結核検診をスムーズに 行なうために，本機を考案し試作したが，拉大撮影を応 用したものであるから被検者を一定距離X線管球に近ず けるため，管球焦点の大きさにより幾何的ボケの抬大を 伴ないとれによる解像力の低下, 距離の逆 2 乗の影響そ の他の影響による皮膚被曝線量の増加および生殖腺被曝 線量が問題となり，これらについて実験を行なった結果， かなり良い結果を得たので報告する。

\section{II 実験結果}

1. 解像力および見易さ

解像力については線于ャートを使用し従来の方式と考 案によるものとでは 1 ポイントだけ少っているが，バー ガーファントームを使用した生理的兌易さでは雨者全く 変りがなく，グリッドを必要としないととがわかった。

2, 皮膚被曝線量および生殖線腺量(推定)乙れらの実

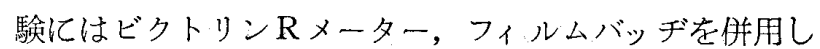
たが，考案によるものはグレーデル効果により二次線除 去用グリッド不要であるからグリッドを取外し測定を行 なった結果，皮膚被曝線量については雨者全く変りがな く生殖腺量については $1 / 4$ とむしろ少ない。

\section{III 䓔 察}

これらの実験に基ずいて小児の撮影を行なった結果考 案によるむのでグリッドを使用したものと使用しないす のでは，グリッド使用しなをいものの方がむしろ見易く 従来の方式による撮影に比べ，コントラストが大人同様 大変よく，幾何的ボケによる欠陷を充分におぎないむし ろ見易い写真が得られた。

\section{IV 結 論}

解像力は劣るが見易さの点は全く変らず，グリッド不 要のため皮膚执よび生殖腺とも線量については問題にな らない。また濃度調整が不要でありコントラストの良い 写真が得られる。 また従来の方式にようて生ずるミスと 煩さがなく，小児を混えた市民検診等ではその威力を充 分に発揮し，目的を充分に果すとるができる.

\section{(翼問)}

蛍光板と管球焦点との距離, および监光板と枠との距 離如何.

（兵庫阿部）

(答)

前者は $90 \mathrm{~cm}$ ，後者は $25 \mathrm{~cm}$ である.

\section{4）円軌道方式断層撮影装置の基礎的研究（量残像と} 歪について)

神銅西宫病院
川鉄西宮工場診療所
明和病院

○後藤 正季
稲 井 敬
岩原 寿老

（目的） 円軌道方式断層撮影装置による断層像の歪， および暈残像がもたらす見かけ上の像の歪について， 像が中心より外れている場合の影響，ファントムを傾斜 させた場合の影響, 選択曝射および振り方向の変化によ る影響，円錐頂角（振り角）との関係，障害陰影の暈像 による影響等, 円弧方式断層影撮装置と比較しながら検 討を加えた。

（方法）装置は円軌道方式(以下サーカストモと略称) として，東芝レヤーグラフ CS-1 型，円弧方式として， 日立断㬝装置 DL-1 型を使用，ファントームは，直径 $2 \mathrm{~cm}$, 高さ $6 \mathrm{~cm}$ のガラス管に水を封入したものを自製し 浸台の上に中心と， $\pm 5 \mathrm{~cm}$ の間隔をおいて 5 本ならべ, 下端より $3 \mathrm{~cm}$ の面を載断面として，断層撮影を行なっ た. ファントームの傾斜角度 $\alpha$ は, 断㻥面に垂直な方向 を $0^{\circ} と し て, 0^{\circ}, 20^{\circ}, 40^{\circ}$ と変化し，障害陰影をつくり 